\title{
The Development in Global Production
}

\author{
Teit Lüthje \\ Department of Entrepreneurship and Relationship Management, University of Southern Denmark, Kolding, \\ Denmark \\ Email: teit@sam.sdu.dk
}

Received 20 February 2015; accepted 7 March 2015; published 10 March 2015

Copyright (C) 2015 by author and Scientific Research Publishing Inc.

This work is licensed under the Creative Commons Attribution International License (CC BY). http://creativecommons.org/licenses/by/4.0/

c) (i) Open Access

\begin{abstract}
The focus of this article is on the way in which the advantages of laying out production are changing in line with countries' economic development. This is the background for some of the challenges connected with problems by laying out of production. As a result the production is moved either on to another distant low wage country, concentrated in a country close to the home country or drawn back to the home country, where it is increasingly subject to automation. Production of more advanced products is located in countries where the demand is about to blossom, and here the automation is also increasingly important. Thereby, to a greater extent, the main motive by laying out production is proximity to the market. Hence it is important to consider the challenges by laying out production in foreign countries.
\end{abstract}

\section{Keywords}

Global Production, Economic Development, Outsourcing and Offshoring, Automation

\section{Introduction}

The increasing globalization implies that companies can operate in a considerably larger marketplace than before and may shift production among different countries with fewer barriers. Because of this development the profitability of companies is determined by specialization in order to be able to differentiate in the sharpened competition. This has led to an extensive global distribution of production. Laying out production can be made to external partners, i.e. subcontractors, and is called outsourcing, or by establishment of subsidiaries in the host country, which is called offshoring. Between these two globalization strategies we have a joint venture which is a business agreement between two or more partners involved in an economic cooperation.

Dunning's eclectic paradigm, the so-called OLI-model (see e.g. [1] and [2]), has long been the most influential framework for investigation of determinants in international production. The OLI-model was intended to provide an overall analytical framework that could include the most important theories for the problem at hand. 
The OLI-model is a summary of various theories specifically related to the formation of multinational companies. However, some companies have had to realize that there are problems connected to the laying out of production in foreign countries. Hence outsourcing and offshoring can lead to both success and failure ([3] and [4]). This especially applies for companies that lay out production just to save labour costs. Finally outsourcing and offshoring can be perceived as competing business strategies used to orchestra a company's value chain ([5] and [4]).

The article provides an insight into some of the problems connected to laying out production to foreign countries and, in continuation of this, which strategies companies take advantage of when they relocate production to other countries. The focus of the article is on the way in which the advantages of laying out production are changing in line with countries' economic development. The next section gives a mind-set of the advantages from laying out production in foreign countries. Section 3 outlines problems connected to laying out production in foreign countries and possible strategies to solve them. In Section 4 possible improvements in productivity through automation are illustrated and Section 5 discusses other factors that affect the long-term competitiveness. Section 6 analyses the impact of economic development on the motive to lay out production. Finally, there are some concluding remarks.

\section{Advantages of Laying out Production to Foreign Countries}

In the following is given an overview of the advantages by laying out production in foreign countries which leads to a mind-set of these advantages. The mind-set is inspired by Dunning's eclectic paradigm, the so-called OLI-model (see e.g. [1] and [2]), which is a summary of various theories specifically related to the formation of multinational companies.

If it is not advantageous to lay out production to another country, the production naturally takes place at home, and globalization benefits are only reflected by export of the finished product. Conversely, if it is advantageous to lay out production to another country, there are several factors one must keep in mind. To put it another way, there are pros and cons no matter what decision is made, and it is therefore important to put them up against each other. Traditionally, the motive for laying out production is the utilization of wage differences between countries. Therefore labour intensive productions are located in labour rich countries, whereas capital intensive productions are located in capital rich countries. In a similar way productivity differences between countries can determine the allocation of production. The production is thus allocated in accordance with countries' factor endowments and thereby utilization of comparative advantages in the individual productions.

Market proximity, i.e. closeness to the end users of the product, is also a key parameter and is determined by the economic development of the countries concerned, as described below. In this context, further benefits may be achieved in relation to saved transport costs and avoidance of import restrictions such as tariffs and quotas. Finally, there may be benefits associated with being geographically close to other similar companies. For instance one can do networking and thus have easier and cheaper access to infrastructure and services.

On the other hand, various conditions must be taken into account when laying out production, which may limit the advantages. Firstly, if the final product is to be forwarded to other countries, related transport costs have to be included in the total costs. Furthermore, one must take into account import restrictions in the countries in which the final good is going to be sold. So depending on the issue, transport costs as well as import restrictions can be seen as either an advantage or a disadvantage. One must also be aware of differences in language, culture (business, management and working culture), law and ideology. Finally, issues such as corruption and bureaucracy also have a negative impact on the advantages of laying out production.

As mentioned in the introduction, there are primarily two alternative ways to lay out production. The laying out typically assumes the shape of either outsourcing, in which the production is delegated to a foreign subcontractor through for example license, or offshoring, in which the production is established in a subsidiary in the host country. The advantages of offshoring are based on the fact that it is inappropriate to export or outsource, as it may involve a risk of for example imitation of the product or less market control. Hence, the reason of offshoring is that the company seeks to protect the generated knowledge and does not want to lose it through the market. Furthermore, control as well as management and leadership are more easily carried out.

The alternative to offshoring is outsourcing, which, for example, can be a standard production that is easily managed by the subcontractor and in which there is no risk of imitation. As another example, the company may have established contact with a particular subcontractor who has the necessary knowledge and experience. Moreover, the choice may be postponed because the company wants to investigate the potential for offshoring. 
The choice of outsourcing versus offshoring may influence the degree of control as well as management and leadership and thereby the advantages from laying out production. Furthermore, the experience gained may sharpen the company's competitive position. These thoughts are illustrated as a mind-set in Figure 1.

It is important that the company is conscious of its capabilities and potential contributions to the global context. Furthermore, the choice between outsourcing and offshoring may have implications for the choice of country, in which the production is located. If a company chooses outsourcing, it may have to choose a country that is characterized by a trustworthy business environment with minimal risk of imitation and the failure of agreements, even though labour costs are not as low as in other countries.

Between these two globalization strategies we have a joint venture which is a business agreement between two or more partners involved in an economic cooperation. The agreed distribution of power is vital to the advantages of this globalization strategy. In a joint venture the single partner will have more influence and control than in outsourcing, and a joint venture does not bind financially in the same way as offshoring.

\section{Problems Connected to Laying out Production and Possible Strategies to Solve Them}

As mentioned above, the economic growth in China has caused wage increases of more than 10 percent per year (se for instance "Trading Economics"), which has reduced the cost advantages from locating production in the country. At the same time, production in the home countries of many companies has become cheaper, because the companies used the crisis to streamline and automate production, more about this in Section 4.

In addition to the problem related to the reduction in the cost advantages are problems with product quality, inadequate infrastructure, longer lead-time, lack of control and management as well as more complicated procedures. In countries outside Europe is often seen a smaller work ethic, self-reliance, initiative-taking and company loyalty than in European countries, together with is a lack of flexibility in the labour market. Furthermore, several companies have experienced that "tacit knowledge", i.e. experience from many years of work, cannot just be transferred to other workers, but needs to be learned. Finally, language and cultural barriers, and lack of communication have caused problems.

Companies typically use one of the following three different strategies, when they withdraw production from a country:

1) The production is moved on to another distant low-wage country.

2) The production is concentrated in a country close to the home country, where wages are higher than in the distant low-wage country, but lower than in the home country.

3) The production is moved back to the home country and increasingly subject to automation including the use of robots.

The first strategy, moving the production to another distant low-wage country, is used, for example, when

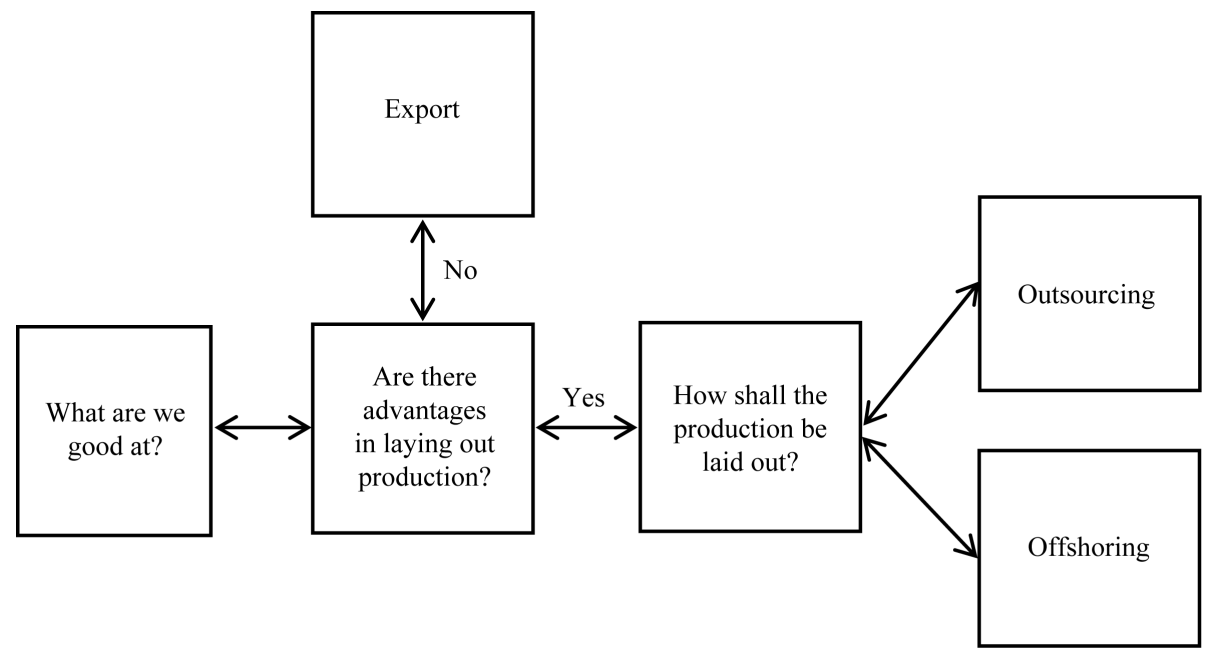

Figure 1. A mind-set about laying out production. 
companies move production from China to Vietnam. In this case, there may, over time, be wage increases in Vietnam corresponding to those in China. A more recent and different trend includes the other two strategies, according to which companies instead choose to concentrate the production in a country close to the home country or to draw production back to the home country. When an outsourced production is withdrawn to own companies, the process is called back sourcing.

By moving the production back to the home country or a country nearby, the company will have a shorter reaction time in case of sudden changes in the market and easier access to controls and product development. Furthermore, the company obtains a stable production flow as well as a better management of the value added chain and achieves a more simple structure of the entire organization. All this is particularly important if a company is constantly developing new products, producing many types of products or few units of each product type. Finally, by concentrating the production in fewer locations a company improves its opportunities to benefit from economies of scale.

The reason why some companies choose to withdraw production to the home country is the efficiency improvement and the increase in technology that have taken place in the home country, see the following section. In addition, in Western countries many employees are characterized by being independently thinking, loyal, innovative, possessing a strong work ethic and able to take initiatives. This, together with a short response time and improved access to control and management as outlined above, compensates for the fact that in some countries domestic wages are relatively high. Companies should of course only take the production home which they have competences to carry out, and, furthermore, they should consider necessary investments in means of production. Hiring the right people is a necessary condition, in which professional qualifications as well as personality are central issues.

\section{Possible Improvements in Productivity through Automation}

As mentioned above, the reason why some companies choose to withdraw production to the home country is the efficiency improvement and the technological developments that have taken place in the country. In recent years the technological developments are reflected by the significant raise in robot technology. Furthermore, the price of a robot has decreased to about 25 percent in recent years and robots are far more flexible, easily programmed and can be used for far more tasks than earlier. In addition to lower cost automation can also lead to a lower error rate, time savings, less waste and improved working environment. The challenges of automation can be time and resource problems and lack of technological knowledge.

But there are even more benefits to come by even greater use of the opportunities for technology boost and automations. [6] analysed the importance of automation in the manufacturing sector. Automation is measured by the number of industrial robots per million hours of work. Among other things Lene Kromann et al. analysed the effect on productivity and employment within each industry with automation as in the most automated country. This means, however, that the analysis does not allow for future technological boosts, whereby the results may be underestimated. The productivity changes for the authors' selected nine countries are presented in Table 1. The gain in productivity for the most automated country is $0.0 \%$, and the country is listed in the column "Best".

The key message of the table is that the productivity of all countries included in the analysis can be increased, if the same automation as in advanced countries is used. Germany is leading within transport equipment, Japan is leading within electrictronic equipment and Italy is leading within chemical products. Furthermore, although Denmark is leading within metal and machinery, textile and leather as well as wood and furniture, the average productivity can be increased by $15.2 \%$ with automation as in the most automated countries.

In the short run, automation will lead to a decrease in employment due to the higher productivity, which implies a reduced need for unskilled labour. However, in the long run employment can be increased due to the improved competition, and there will be an increased need for skilled workers and engineers. Productivity gains from automation will eventually be even greater, since it is expected that a significant proportion of the industries will automate and thereby improve competitiveness.

\section{Other Factors That Affect the Long-Term Competitiveness}

It is obviously important to focus on what a country's companies are good at producing and what they should focus on in the global competition. If a country has a strong position in research, development and innovation, the country has a competitive advantage in terms of quality, design and service. The extent of export of high 
Table 1. Productivity changes if automation as in the most automated country. Percent.

\begin{tabular}{ccccccccccc}
\hline & Best & Japan & Germany & UK & France & Italy & Spain & Sweden & Finland & Denmark \\
\hline Food, tobacco & Finland & 13.7 & 8.7 & 13.7 & 11.4 & 11.7 & 11.2 & 7.1 & 0.0 & 7.4 \\
Textile, leather & Denmark & 9.7 & 8.8 & 9.7 & 9.3 & 9.6 & 9.5 & 9.7 & 8.6 & 0.0 \\
Wood, furniture & Denmark & 21.5 & 1.2 & 21.0 & 20.4 & 19.8 & 18.7 & 17.4 & 19.7 & 0.0 \\
Paper, publishing & Finland & 2.1 & 1.8 & 2.8 & 2.0 & 2.3 & 2.5 & 2.5 & 0.0 & 1.9 \\
Chemicals products & Italy & 13.0 & 12.2 & 29.4 & 22.2 & 0.0 & 24.3 & 19.6 & 10.2 & 20.7 \\
Glass, ceramics, stone & Germany & 8.2 & 0.0 & 9.6 & 6.7 & 7.2 & 7.7 & 8.5 & 6.8 & 4.0 \\
Metal. machinery & Denmark & 5.5 & 5.1 & 11.7 & 8.7 & 6.2 & 8.7 & 1.0 & 3.7 & 0.0 \\
Electrictronic equipment & Japan & 0.0 & 16.8 & 24.2 & 22.5 & 22.2 & 22.3 & 20.3 & 13.9 & 16.8 \\
Transport equipment & Germany & 15.9 & 0.0 & 76.3 & 28.5 & 8.1 & 36.0 & 65.8 & 80.2 & 81.4 \\
All other & Japan & 0.0 & 27.9 & 41.3 & 40.0 & 39.3 & 38.8 & 39.3 & 39.0 & 39.6 \\
Total & & 8.1 & 8.0 & 22.3 & 15.4 & 10.5 & 16.3 & 15.7 & 14.9 & 15.2 \\
\hline
\end{tabular}

Note: The "Total” is the employment weighted average of the productivity change in all industries. Source: [6] page 13.

quality products can be taken as an expression of what is relevant to global competitiveness and provide indications as to which factors are central to this competitiveness. Companies in high-cost countries produce many high quality products because quality, design and service concepts can be sold at a higher price compared to similar products from other countries. However, it should be kept in mind that typically within a short period of time a price pressure is put on high quality products, because competitors may copy the properties of these products.

[7] has estimated the export of high quality products to the EU15 countries by using so-called upmarket products. The export of upmarket products comprises products that are at least $15 \%$ more expensive than the average product in the EU15 countries. 85\% of Swiss exports to the EU15 countries consist of upmarket products, ensuring the country a clear first place ahead of Japan and Ireland, who are number two and three on the ranging list. The proportion of upmarket products is also relatively high in countries as USA, Israel, Australia, Canada and Denmark. So, for part of the export from these countries the price including wages is not essential, which is reinforced by the fact that the labour-intensive part of the production is subjected to automation and efficiency improvements. Instead of lowering wages in order to maintain competitiveness, companies should rather focus on wages not becoming too low. Suitable wages may be important to attract sufficiently skilled and educated employees and to make sure that employees retain the incentive to make a noticeable contribution. On the other hand, the proportion of upmarket products is low in countries such as Norway, Poland, Spain, Turkey, India, Brazil and China. Therefore these countries are more vulnerable in terms of prices in global competition.

Logistics is another factor with implications for the global competition. A short lead time for goods and services is important, as well as focus on fast adjustment to new processes. Storages should be as small as possible, and one must buy, produce and deliver just-in-time and minimize waste. The delivery performance is therefore a key factor of competitiveness.

\section{Impact of the Economic Development on the Motive to Lay out Production}

In line with increased trade and increased investments in developing countries, in which the production is located, the economic growth in these countries increases faster than in the developed countries. This impacts the production as well as the demand of the developing countries and thereby also the advantages by locating production in these countries. The countries' supply of production factors becomes more capital intensive and is lifted to a higher level of technology. At the same time the level of education increases, whereby production becomes more advanced. This implies that in terms of production these countries will increasingly look like the developed countries. Furthermore higher levels of education and improved technology and, in continuation of this, new knowledge give the developed countries further advantages when investing in these countries. 
In step with the rising wages, demand will also be lifted and directed to differentiated products at a higher quality level, at which the developed countries has a strong position. This change in the purchasing power helps reinforcing proximity to market as a key factor. The Chinese middle and upper classes to a large extent demand Western brands within vehicles, clothes, bags, food and wine. The same situation applies within e.g. the wind power industry. The rapidly growing Chinese middle class may create a market for products that are "good enough" to be sold at a price that the Chinese middle class can afford. Such products need central attention in order to enter a fast growing market and to establish contacts in the immediate environment. Such trend in consumption is typically followed by lifestyle diseases in which pharmaceutical products also come into consideration. Therefore, the above considerations about the advantages of withdrawing production from for example China do not apply for companies that lay out production for the sake of proximity to market or utilization of knowledge.

The economic development in the developing countries leads to increasing wages which are the reason why cost advantages from laying out production decrease over time. However, the disadvantage of increasing wages in developing countries may be matched by automation. Accordingly, the main focus has to be on the advantages from laying out the production, whereby proximity to the market is of increasing importance and over time it can be better handled by automation.

\section{Conclusions}

It appears from the article that the motive for laying out production changes in line with the economic development in the countries in which the production is located, which is the reason for some of the challenges companies encounter in this context. As a result the production is moved either to another distant low-wage country or is concentrated in a country close to the home country or is withdrawn to the home country, in which it is increasingly subject to automation.

Production of more advanced products is located in countries in which the demand is about to blossom. This economic development has been reinforced by the developed countries through trade, outsourcing and investments associated with offshoring. In this context automation is also increasingly important to match the rising wages in these countries. Thereby the main motive of laying out production is proximity to the market.

Due to the economic growth in developing countries, companies in these countries also invest in Western countries. Relative to Hong Kong and China seen as a whole and in relation to Singapore the inward investment is increasing, though still lower than the outward investment from these countries. For example, China is investing in health and environmental technology. Chinese investors also go for shipping, machinery, IT, real estate, food, clothing and industrial design. The Chinese interest is no longer limited to purchases of foreign companies with rights to natural resources such as mining and oil companies, which can be explained by their rapidly growing domestic market. Through Chinese investment Western companies may obtain technology and new knowledge from China. Technology that can be built upon thereby also create growth and jobs.

\section{References}

[1] Dunning, J.H. (1993) Multinational Enterprises and the Global Economy. Addison-Wesley Publishing Company, Reading.

[2] Dunning, J.H. and Lundan, S.M. (2008) Multinational Enterprises and the Global Economy. 2nd Edition, AddisonWesley Publishing Company, Reading.

[3] Kinkel, S. and Maloca, S. (2009) Drivers and Antecedents of Manufacturing Offshoring and Backshoring-A German Perspective. Journal of Purchasing \& Supply Management, 15, 154-165. http://dx.doi.org/10.1016/j.pursup.2009.05.007

[4] Arlbjørn, J.S. and Lüthje, T. (2012) Global Operations and Their Interaction with Supply Chain Performance. Industrial Management \& Data System, 112, 1044-1064. http://dx.doi.org/10.1108/02635571211255014

[5] Mudambi, R. and Venzin, M. (2010) The Strategic Nexus of Offshoring and Outsourcing Decisions. Journal of Management Studies, 47, 1510-15. http://dx.doi.org/10.1111/j.1467-6486.2010.00947.x

[6] Kromann, L., Skaksen, J.R. and Sørensen, A. (2011) Automation, Labour Productivity and Employment—A Cross Country Comparison. Working Paper, CEBR, Copenhagen Business School, Copenhagen.

[7] Danish Industry (2014) Global Benchmark Report 2014. http://di.dk/Pages/Forsiden.aspx 